\title{
Bartók and the Violin Music of Maramureş
}

\author{
Viola BIRÓ*
}

Budapest Bartók Archives, Institute for Musicology, Research Centre for the Humanities, Táncsics Mihály u. 7., H-1014 Budapest, Hungary

\section{ORIGINAL RESEARCH PAPER}

\author{
Received: May 2, 2018 • Accepted: February 9, 2020
}

(c) 2021 The Author

\begin{abstract}
The Second Rhapsody, one of Bartók's technically most demanding concert pieces for violin, arranges archaicimprovisatory bagpipe imitations for concert performance. The arrangement itself shows a well-designed, coherent structure: the succession of dances, tonally and motivically related between each other, outline a kind of evolutionary progression from free motive-structure to strophic form. Bagpipe-music had a long-term influence on Bartók's violin music, figuring as episodes in original works like the two Violin Sonatas or the Violin Concerto; but none exploits the genre to such an extent as the Second Rhapsody. The violin pieces with motivestructure of fascinatingly wild and virtuoso character were among Bartók's major discoveries of the collecting trips to the Maramureş region. For the Rhapsody Bartók chose melodies from the one-time Ugocsa county, whose music, closely related to that of Maramureş county, was considered by him "the most interesting in our country [i.e., Hungary of the time], due exactly to its primitive character." In Maramureş these melodies are less eccentric; instead, the violinists have a broader and more varied repertoire of dance music. In my article I discuss the different types of violin music of this region, focusing on structural, melodic, or interpretational elements that were of special interest for the composer. For this investigation I have made use of the primary sources of the respective collections: phonogram recordings, field notations, later transcriptions.
\end{abstract}

\section{KEYWORDS}

Bartók, Romanian folk music, dance music of Maramureş, motivic dances, Sonata for Violin and Piano no. 1

When in the last months of 1912 Bartók started to prepare his folk music collecting trip to Maramureș County, he contacted the Romanian folklorist Tiberiu Brediceanu, whom he knew had explored the same area. Characteristically, he made inquiries about distinct problems which were of special interest for him:

\footnotetext{
*Corresponding author. E-mail: biro.viola@abtk.hu
} 
... I should still very much like to know the following:

(1) Whether you have found any difference between old and new songs (did only old people know the old ones and young people the new ones?)

(2) Whether the old-style "horă" (as the rubato singing is called there instead of "doina") is only one single melody, or whether several forms of it can perhaps be found. I.e., in the 8 Romanian villages of Ugocsa there is only one single melody of "horă," which is sung in a characteristic fashion with guttural hiccupping ...

(3) Does the "strigături" shouted for the peasant dance also begin with "Hei țuraaaa," and is this peasant dance, too, just the continuous repetition of a short (2-measure) motif? ${ }^{1}$

The two genres mentioned here - the so-called hora lungă and the dance melodies with motif structure - would become of central importance in his monograph discussing the folk music of Maramureș County. ${ }^{2}$ The hora lungă or "long-drawn" melody, ${ }^{3}$ regarded by Bartók as an archetype of Romanian folk music, proved to be one of Bartók's most important findings in all his ethnomusicological research, that later became his favorite example in illustrating the relationship between folk melodies of different nations of different continents. ${ }^{4}$ This highly ornamented melody type of free, improvisatory character is considered to have had a great impact on the composer's own music, too: let us mention only the opening theme of the Second Violin Sonata (BB 85), the violoncello solo of the third movement of the Fourth String Quartet (BB 95), or the tenor solo of the Cantata profana (BB 100). ${ }^{5}$ The dance melodies with motif structure also belong to an archaic stratum of the folk music in question; these will be discussed

\footnotetext{
${ }^{1}$ Bartók's letter of 16 December 1912 to Brediceanu, Bartók Letters. The Musical Mind, ed. by Malcolm GILLIES and Adrienne GOMBOCZ, unpublished typescript in the Budapest Bartók Archives.

${ }^{2}$ Béla BARTÓK, Volksmusik der Rumänen von Maramureş (Munich: Drei Masken Verlag, 1923). In facsimile reprint: Béla BARTÓK, Ethnomusikologische Schriften II, ed. by Denijs DILLE (Budapest: Editio Musica, 1966). In English: Béla BARTÓK, Rumanian Folk Music, ed. by Benjamin SUCHOFF, vol. V: Maramureş County (The Hague: Martinus Nijhoff, 1975). The monograph was compiled soon after the collecting trip in March 1913 and intended to be published shortly by the Romanian Academy, but due to the outbreak of the First World War it came to be published only a decade later in Munich in the publication series Sammelbände der Vergleichende Musikwissenschaft under the auspices of Carl STUMPF and Erich von HORNBOSTEL. Although the musical part of the volume dates back to 1913-1914, the introductory study was significantly revised. For the differences of the two versions see the editorial preface by Denijs Dille and Appendix I (printing excerpts from the first version of the introductory study) in the 1966 facsimile reprint. For a detailed publication history see Ferenc LÁSZLÓ, "Nochmals über die Entstehungsgeschichte der rumänischen Folkloresammlung von Maramuresch,” Studia Musicologica 23 (1981), 329-351.

${ }^{3}$ The description of the genre given in the Maramureş monograph marks an essential point of reference in the research history of the Romanian doina, see Eugenia CERNEA, Doina din Maramureş, Oaş şi Bucovina [The Doina from Maramureş, Oaş and Bucovina] (Bucharest: Global, 2011).

${ }^{4}$ See Bartók’s lecture "Some Problems of Folk Music Research in East Europe," in Béla Bartók Essays, ed. by Benjamin SUCHOFF (London: Faber \& Faber, 1976), 173-192.

${ }^{5}$ See, e.g., John W. DOWNEY, La musique populaire dans l'œeuvre de Béla Bartók (Paris: Centre de Documentation Universitaire, 1966), 97, 341, 348-349; László SOMFAI, “Bartók Béla: 2. Hegedű-zongora szonáta” [Béla Bartók: Sonata for Violin and Piano no. 2], in A hét zenemüve [Composition of the week], ed. by György KROÓ (1977/4), 44-55; Péter LAKI, "Der lange Gesang als Grundtyp in der internationalen Volksmusik," in Studia Musicologica 24 (1982), 393-400; Yves LENOIRE, Folklore et transcendence dans l'œuvre américaine de Béla Bartók (1940-1945): Contributions à l'activité scientifique et créatrice du compositeur (Louvain-la-Neuve: Institut supérieure d'archéologie et d'histoire de l'art, 1986), 333-334; László VIKÁRIUS, “Béla Bartók’s Cantata profana (1930): A Reading of the Sources," in Studia Musicologica 35 (1994), 249-301.
} 
further on in detail. Let us mention here only, that due to their structural peculiarity Bartók paid special attention to these melodies: through their analysis and double classification in the instrumental volume of his posthumously published collection Rumanian Folk Music, he arrived at one of his most original and complex systematizations of a folk repertory. ${ }^{6}$

Bartók first encountered these two genres during two short collecting trips in the neighboring territory of the one-time Ugocsa County (the ethnographic region of Oaş, now part of Satu Mare County). ${ }^{7}$ Although the relatively modest result of these trips would not have made possible the comprehensive analysis of the territory's music, it was sufficient to call Bartók's attention to the highly individual features of its repertoire. As Bartók states in the introductory study of his Maramureş monograph, the folk music of Ugocsa County is closely related with that of Maramureș. In Bartók's terms, they belong to the same northern dialect of Romanian folk music. As he repeatedly points out, however, the music of the Ugocsa-Avas territory is more archaic and appears to be of almost untouched character. The fact that the two genres, the hora lung $\breve{a}$ and the dance melodies with motif structure, have a lively, almost exclusive existence in Ugocsa constitutes for Bartók a strong argument in support of his statement about the archaic qualities of these melodies. ${ }^{8}$ In his aforementioned letter to Brediceanu, Bartók refers to it as follows: "The ancient music of the Romanians of Ugocsa is the most interesting in our country precisely because of its primitiveness." In the following survey of the violin music of Maramureş we will first take a short look at the relevant repertoire of this folk music dialect, outlining its main characteristics in the counties of Maramureş and Ugocsa, respectively. This will be followed by two case studies attempting to illustrate the different ways in which elements of this folk music infiltrate into Bartók’s music.

The dance music of Ugocsa (Oaş) territory is characterized by a rare stylistic unity compared to other ethnographic regions of Romanian dance music. ${ }^{9}$ Later researchers confirm that the peculiar formal structure of the melodies, that Bartók emphasized so much, play a decisive role

${ }^{6}$ Béla BARTÓK, Rumanian Folk Music, ed. by Benjamin SUCHOFF, vol. I: Instrumental Melodies (The Hague: Martinus Nijhoff, 1967). For a detailed discussion of Bartók's different analytical approaches to these melodies see László SOMFAI, "Bartók népzenei forma-terminológiája” [Bartók’s terminology of folk music forms], in id., Tizennyolc Bartók-tanulmány [Eighteen Bartók studies] (Budapest: Editio Musica, 1981, 2nd ed. 2014), 279-297.

${ }^{7}$ The collection took place at 20-22 January and 13-15 (?) April 1912, in the villages of Tarna Mare, Comlăuşa, and Turț. For a detailed discussion of Bartók's Romanian folk music collections see Francisc LÁSZLÓ, Béla Bartók şi muzica populară a românilor din Banat şi Transilvania [Béla Bartók and the folk music of Romanians from Banat and Transylvania] (Cluj-Napoca: Eikon, 2003), 21-36.

8"In older times, the Hora lungă was indubitably the only melody used in Maramureş, for lyric and epic texts. This hypothesis is fortified by the fact that in the Ugocsa Rumanian musical dialect, neighboring upon and closely related to that of Maramureş, though more intact, practically speaking only this single Hora melody is known up to the present day." "The aboriginal aspect of these melodies [i.e., melodies of free structure] derives not only from their primitive character, but also from the fact that only this kind of dance music is encountered in the nearly virgin, extremely primitive Ugocsa-Avas territory." See Maramureş, ed. by SUCHOFF, 11, 25.

${ }^{9}$ Though it has gone through considerable changes since Bartók's collecting trips, this dance music tradition is still nowadays very much alive. See Anca GIURCHESCU and Sunni BLOLAND, Romanian Traditional Dance: A Contextual and Structural Approach (Mill Valley, CA: Wild Flower Press, 1995), 259-261; Jacques BOUËT, Bernard LORTATJACOB, and Speranța RĂDULESCU, À tue-tête: Chant et violon au Pays de l'Oach, Roumanie (Nanterre: Société d'ethnologie, 2002). 
in creating this uniform image. ${ }^{10}$ In Bartók's analysis and systematization of folk melodies structural criteria are always of crucial importance; in the collected edition of his Romanian collection the classification of instrumental dance melodies are governed predominantly by structural aspects. In consequence, the violin pieces of Ugocsa, defined as "melodies with motifstructure," are classified - along with a great amount of bagpipe and several peasant flute melodies - as an independent group (class B in Volume I of Rumanian Folk Music). ${ }^{11}$ In the Maramureş monograph Bartók gave the following definition about melodies belonging to this group:

Dance melodies in free form are made up of one or more two-bar motifs which are repeated without interruption and which are without fixed form or ending. ... They are played on the violin or the shepherd's flute, but with rare exceptions sound like imitations of the bagpipe. Probably in earlier times the bagpipe was the only instrument used for dances. However, it ceased to be used in this area about twenty or thirty years ago. ${ }^{12}$

As later scholarship reveals, structural organization based on motivic repetition - also named twin-bar structure or melodies of twin-bar motifs in current literature - belongs to the oldest layer of instrumental folk music connected pre-eminently to the bagpipe, the "number one instrument of dance music."13 In Bartók's collection the majority of motivic melodies are indeed bagpipe melodies. The most significant part of it, the rich repertoire of Lazăr Lăscuş, a young virtuoso bagpipe player from the Hunedoara region, deserves special attention in several respects. Lăscuş was the key figure of an important Budapest lecture in 1914, Bartók's first public presentation as an ethnomusicologist (and the only one with live illustration of peasant performers), that resulted in the very first gramophone recordings of folk music in Hungary. ${ }^{14}$ Moreover, analyzing the motivic material of Lăscuş's melodies and his technique of motivic variation Bartók raised the question - that could have been answered only by further collections - whether all his motifs were rooted in tradition or one part of them was the result of the performer's creative imagination. ${ }^{15}$ Bartók's decisive encounter with Lăscuş, however, was subsequent to his Maramureş and Ugocsa collections. Previously, he heard bagpipe music with similar structure in the Bihor region (1910) as well as from Hungarian bagpipers in the one-time northern Hungary

\footnotetext{
${ }^{10}$ See Iosif HERȚEA, "Câteva particularități stilistice ale muzicii de joc oşeneşti” [Some stylistic features of the dance music from Oaş], in Revista de etnografie şi folclor 15, no. 2 (1970), 113-120.

${ }^{11}$ Regarding the large number of melodies with determined structure (class A) Bartók excuses himself for the "shortcoming of the grouping system," that did not allow him to classify them according to different dance melody-types (see $R F M / \mathrm{I}, 50)$. The preliminary manuscript of this material, however, shows that before finalizing the classification Bartók preserved and analyzed them still grouping them according to dance genres (see the manuscript master sheets of Bartók's Romanian collection preserved in the Hungarian Bartók estate, Gábor Vásárhelyi’s collection, BH I/167-182, photocopy in the Budapest Bartók Archives).

${ }^{12}$ Maramureş, ed. by SUCHOFF, 24 (citation revised on the basis of the original Hungarian wording, see Maramureş, ed. by DILLE, 248).

${ }^{13}$ See Bálint SÁROSI, Bagpipers, Gypsy Musicians: Instrumental Folk Music Tradition in Hungary (Budapest: Institute for Musicology RCH HAS, Nap Kiadó, 2017), 92.

14“The folk music dialect of the Hunedoara Rumanians," in Essays, 103-114. The lecture version is published in Bartók Béla írásai [Béla Bartók writings], vol. 3, ed. by Vera LAMPERT and Dorrit RÉVÉSZ (Budapest: Editio Musica, 1999), 393-405.

${ }^{15}$ RFM/I, 50-51.
} 
(1911), but Bartók recognized their connection only later. ${ }^{16}$ Yet when hearing the violin music of the Ugocsa County, it was obvious for Bartók that it belonged to the bagpipe legacy.

The very first violin melody recorded on Bartók's phonograph cylinders in Ugocsa was actually called by the performer an imitation of bagpipe music (RFM/I, no. 652). ${ }^{17}$ Bartók draws the conclusion that

if a piece is specially designated in this area as an imitation of bagpipe music, there certainly must be a kind of super-imitation or ... a sort of caricature. And this we will find, when we closely examine No. 652. Here it appears as if the player wants to overemphasize those funny squeaking, squealing, and jumpy sounds of the bagpipe. ${ }^{18}$

This strange, somewhat grotesque melody will appear accelerated at a tempo one and a half times quicker than the original in Bartók's Second Violin Rhapsody (BB 96a) at the climax preceding the middle section of the second, Friss [Fast], part. Just before it Bartók quotes another melody from the same gypsy violinist of Tarna Mare, recorded on the same cylinder (RFM/I, no. 653b). ${ }^{19}$ This time the melody, in comparison with the original tempo, is slightly slowed down, perhaps in order to highlight its dense texture and peculiar motivic variation; moreover, Bartók rounds off its structure to a certain degree by either leaving out or introducing certain segments. The original folk melody is confusing at first hearing (see Example 1a). Though its structure is not easily recognizable, it is made up of the repetition and variation of a single twin-bar motif as well as an introductory and a final section. ${ }^{20}$ The heavily ornamented exotic sounding music of wild, capricious character that brings to life this simple skeleton is perhaps its most striking feature. Its unusual character lies to a great extent in its peculiar technique of using open strings that, scattered regularly along the melody line, resembles the drone pedal of the bagpipe. Although this and many similar melodies were not mentioned as

\footnotetext{
${ }^{16}$ In the Bihor monograph these structural aspects have not been discussed yet, in Rumanian Folk Music, in contrast, almost all dance melodies of Nicolaie Bortiş, the bagpiper of Câmp are classified among melodies with motif structure, see Béla BARTÓK, Cântece poporale româneşti din comitatul Bihor / Chansons populaires roumaines du département Bihar (Bucharest: Librăriile Socec \& Comp. şi Sfetea, 1913), melodies nos. 346-352. In his article "Instrumental music folklore in Hungary" (1911-1912) Bartók described the interlude music based on two-measure units of Hungarian bagpipers - called "aprája" - in a similar manner to what would appear in the Maramureş monograph, mentioning that this feature "is non-existent among the Rumanians." See "The Folklore of Instruments and Their Music in Eastern Europe," in Essays, 262. In the Rumanian Folk Music, however, he mentions them as two structurally related melody types (see RFM/I, 51).

${ }^{17}$ See Bartók's notes regarding this melody in his collecting field book “T.III” (Gábor Vásárhelyi’s collection, BH I/110, $32 \mathrm{v}$, photocopy in the Budapest Bartók Archives) and the first transcription of the melody and its phonograph recording (MH 1976a) published in Vera LAMPERT, Folk Music in Bartók's Compositions: A Source Catalog (Budapest: Helikon, 2008), 167.

${ }^{18}$ RFM/I, 694.

${ }^{19}$ See LAMPERT, Folk Music in Bartók's Compositions, 166.

${ }^{20}$ Although Bartók analyzed the motivic content of this melody on the master sheet, it is published without motivic marking in Rumanian Folk Music. The difficulty of interpreting certain motifs was probably the main cause for leaving the analysis out from the final work. This indicates also that the motivic analysis on the master sheet of the main variant of the melody (RFM/I, no. 653a) played by the same violinist was also changed in the Rumanian Folk Music, though this shows a clearer structure. This piece was the first violin melody Bartók heard and recorded in Ugocsa, but its phonograph recording became damaged in the meantime (see Bartók's collecting field book “T.III," BH I/110, 32v).
} 

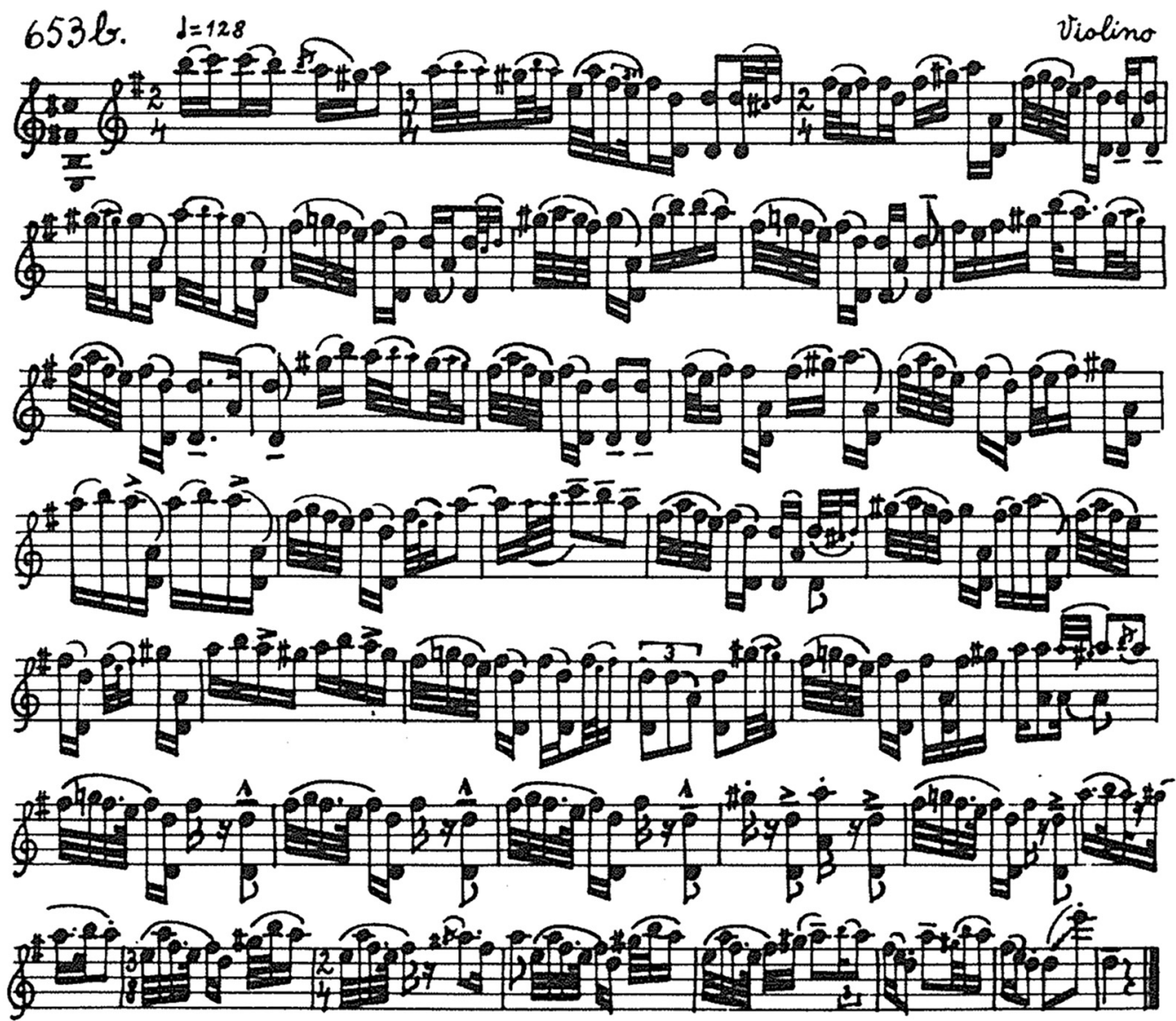

M. F. 1976 c) Jârna-Share (Yatu-Mare), un tigan, I. 1912.

Example 1a. Dance melody with motif structure from Ugocsa, RFM/I, no. 653b

bagpipe imitations, their connection with bagpipe music was evident for Bartók. ${ }^{21}$ In the Maramureş monograph he gives a detailed description of their quasi-polyphonic texture where the rhythmic accompaniment on the lower fifth is reminiscent of the middle pipe, whereas the scale of the melody corresponds to the scale of the "chanter," the pipe playing the melody, of the bagpipe. ${ }^{22}$ The scale of the majority of motivic dance melodies of Ugocsa

\footnotetext{
${ }^{21}$ See Bartók's note to melody no. 652, RFM/I, 694.

${ }^{22}$ Maramureş, ed. by SUCHOFF, 24. The description can already be found in the early version of the monograph (see the manuscript draft and copies of the introductory study, Budapest Bartók Archives).
} 

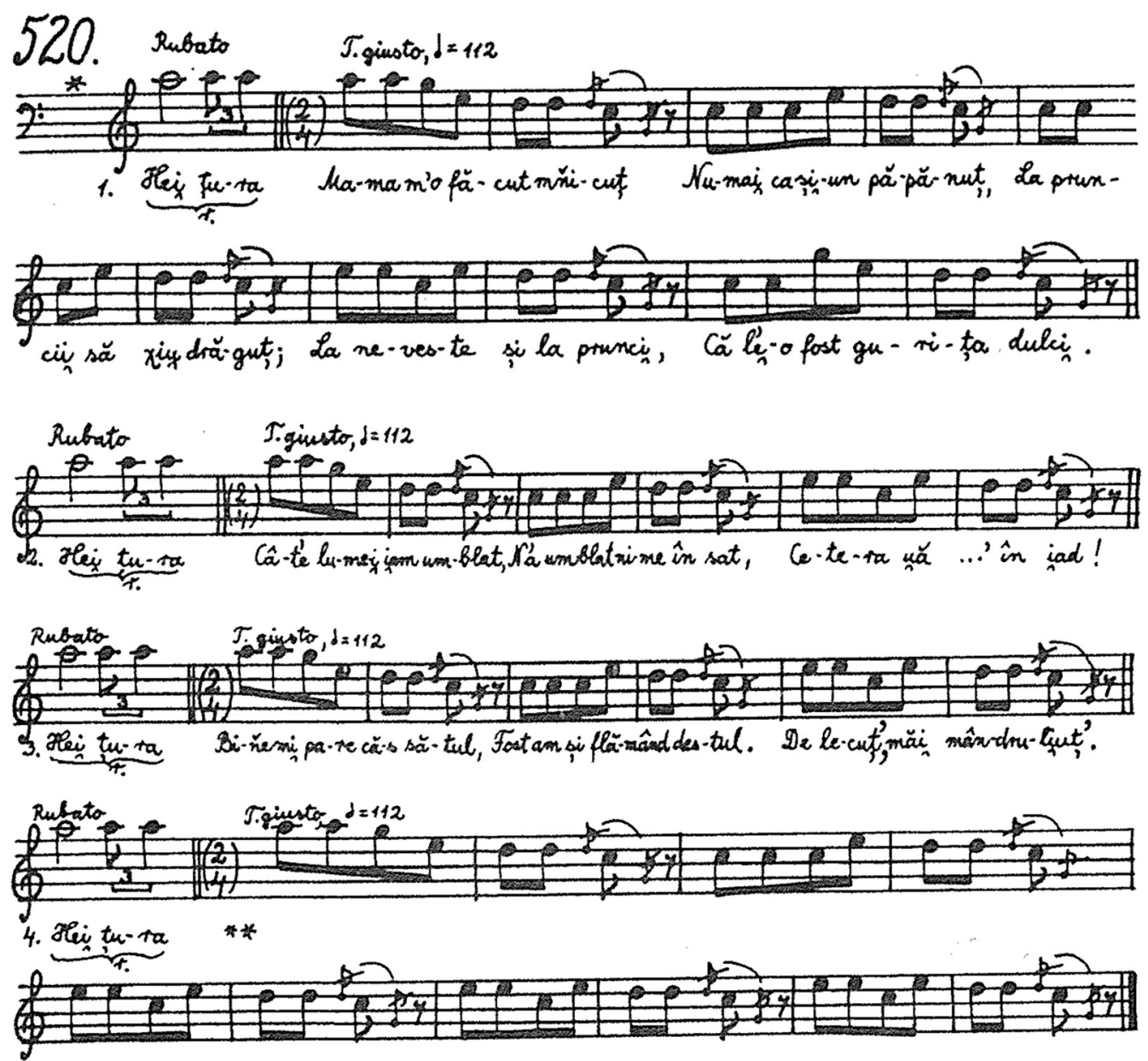

A.F. 1974 a), Jaina.Mare (Sath-Mare), un fecior"t, I. 1912.

Example 1b. Vocal variant of the previous melody, RFM/II, no. 520

as well as of Maramureş is the so-called acoustic scale ${ }^{23}$ that is characteristic primarily of instruments using the overtones of the natural scale, such as the Jew's harp or the tilincă (long peasant flute). Bartók interpreted it, however, as the scale of the once existent bagpipe of

\footnotetext{
${ }^{23}$ Term introduced in Bartók research by Ernő LENDVAI, see, e.g., his The Workshop of Bartók and Kodály (Budapest: Editio Musica, 1983), 394-399. In Hungarian literature the term heptatonia secunda adopted by Lajos BÁRDOS is more commonly used, see, e.g., his study “A Bartók-zene stíluselemei” [Stylistic elements of Bartók’s music], in his Tíz újabb írás 1969-1974 [Ten new articles 1969-1974] (Budapest: Editio Musica, 1974), 27-34. Bartók mentions the scale without any specific name in his Harvard lectures as one of several "seemingly oriental features," see his "Harvard lectures," in Essays, 363; here the scale appears erroneously with minor third, cf. the autograph manuscript of the text, Peter Bartók's collection deposited in the Paul Sacher Foundation, Basel (photocopy in the Budapest Bartók Archives).
} 
this region. ${ }^{24}$ The bagpipe legacy's importance for Bartók is shown by the fact that he includes in the introductory study a detailed description of the bagpipe in square brackets among the relevant instruments of the region. ${ }^{25}$ In this respect the melodic material of Ugocsa was particularly significant for him, since "the gypsies from the Ugocsa-Avas region preserve with astonishing purity the melodies inherited from the bagpipe." 26

The violin repertoire of Ugocsa was only published posthumously in Bartók's Rumanian Folk Music, but it represented a constant point of reference in his analyses of the music of the Maramureş music dialect in his 1923 monograph. Its musical material, however, could not be included in the volume since this was planned to be a monograph - originally of three authors of a single region intended to offer a comprehensive view of the folk music and poetry of Maramureş County. ${ }^{27}$ Furthermore, Bartók was aware that his collection carried out in three villages of Ugocsa County was far from enough, thus according to the text of the first version of the monograph completed in 1913 he was planning further collecting trips that should cover all villages of the Ugocsa-Avas territory "which deserves the greatest attention precisely because of its primitiveness." 28

The violin music of Maramureş County shows a more varied image compared to that of Ugocsa. Here Bartók found many dance types, some with proper melodies and others differing only in tempo or merely in choreography. ${ }^{29}$ Musically he distinguished between two main categories: melodies of free structure, known already from the Ugocsa repertoire, and dance melodies with closed form, represented by a considerable number of melodies in his Maramureş collection. The accurate musical-structural analysis of this latter repertoire provided in the introductory study of his Maramureș monograph gives an idea of the diversity of these melodies. ${ }^{30}$ Also their manner of performance differs considerably from that of Ugocsa: All dance melodies played on violin are usually accompanied by a two-stringed guitar (called zongoră or cobză), that plays an obstinate rhythm of eighth-notes on the $d-a$ fifth, thus actually it is a rhythmic accompaniment. ${ }^{31}$

\footnotetext{
${ }^{24}$ In the Bihor region the bagpiper of Câmp played melodies with motif structure making use of a similar scale, though with neutral fourth degree (see melodies nos. 626, 627, 639a and b, 640, 641 in RFM/I).

${ }^{25}$ Maramureş, ed. by DILLE, XXVII-XXVIII. In the English edition this passage is printed without brackets.

${ }^{26}$ Maramureş, ed. by SUCHOFF, 29.

${ }^{27}$ Before his Maramureş collection Bartók turned to Brediceanu precisely because he wanted to know where he had done research previously, so that their collection could complement each other in their planned joint publication. For further information on the subject see LÁSZLÓ, "Nochmals über die Folkloresammlung von Maramuresch."

${ }^{28}$ See Maramureş, ed. by DILLE, 233 (English translation of the citation is by the author; originally written in Hungarian, published in German).

${ }^{29}$ See Maramureş, ed. by SUCHOFF, 23-25. In Ugocsa Bartók did not record any dance names. According to later ethnomusicological researches in Oaş the generic denomination of all dance types is Danț, see Giurchescu: Romanian Traditional Dance, 259-260.

${ }^{30}$ Maramureş, ed. by SUCHOFF, 25-27. This analysis is missing from the early version of the introduction. This kind of close morphological analysis supported with complex statistical tables is a typical extension in the revised version (ca. 1918) that, according to Dille, "progresses from analysis to synthesis" and in which Bartók had actually found "his personal method and style" (see Maramureş, ed. by DILLE, $8^{*}$ )

${ }^{31}$ In some villages Bartók came across a second violin as accompanying instrument, but he did not include their part in his transcriptions of the melodies nor did he mention it anywhere in his articles probably due to their awkward harmonic content, cf. phonograph recordings MH 2116c, 2120a, 2124a-b, 2139a (melodies nos. 145, 64a, 129 and $173 \mathrm{f}$ of Maramureş).
} 
Therefore by the melodies with motif structure the drone notes played in Ugocsa by one and the same solo violin is here substituted by the uninterrupted pedal of the guitar. ${ }^{32}$ Even the melodic line of certain pieces based on closely related motifs shows that the Maramureș examples are simpler, at times less ornamented, displaying a less developed variation technique. Moreover, these occasionally reveal a tendency for periodization indicating a more recent stage of the development of form. ${ }^{33}$ Regarding the interpretation of dance melodies Bartók expressed some reservations about the violinists in Maramureş, considering their melodies in places distorted, "gypsy-like." 34 Comparing the Maramureş melodies of motif structure with those of Ugocsa, we can indeed observe the more organic motivic material of the latter repertoire, whereas in the Maramureş volume many melodies have "foreign" segments, which motivically do not fit into the rest of the piece, or we can even find entire pieces, which Bartók regarded as completely irregular and unanalyzable. ${ }^{35}$

Despite his reservations, Bartók praised the performance of Pătru Drăguş, a violinist from Onceşti, whom he regarded "a praiseworthy exception" playing "considerably less like a gypsy." 36 Bartók collected a particularly great number and a particularly rich variety of dance melodies from Drăguş. He played many motivic melodies, among them an actual bagpipe imitation called Oşăneşte [Oaş-like] used by Bartók in the Second Violin Rhapsody, ${ }^{37}$ and several melodies of closed structure, one of which is the Jocul ursului [Bear Dance] arranged in 1915 as the second movement of the Sonatina (BB 69). ${ }^{38}$ It is worth mentioning that when in 1913 Bartók came into contact with Erich von Hornbostel, head of the Berlin PhonogrammArchiv, he sent ten of the most valuable cylinders of his collection to Berlin to be copied, in the hope of a possible institutional collaboration. Seven out of the ten cylinders were from his freshly collected Maramureş material, four of them containing hora lungă melodies and two complete cylinders containing recordings of Drăguş's performance as representative of the violin music of the Romanians. ${ }^{39}$ These last two cylinders (MH 2190 and 2192) contain altogether six melodies, out of which the four motivic melodies, two pairs of variant melodies actually, were

\footnotetext{
${ }^{32}$ Bartók remarks that the use of the guitar appeared supposedly only in recent times, see Maramureş, ed. by SUCHOFF, 30.

${ }^{33}$ Cf., e.g., the very first melody of "undetermined form" (no. 136) of the Maramureş volume.

34"The gypsy, however, plays now for the dances of the peasants, and now for the gentlemen; he intrudes everywhere due to his own inconstant temperament, imports all kinds of foreign music, fuses all these elements, adorning them with flourishes learned from cultivated West European society and plays, finally, dance music in which even the connoisseur of folk music finds it difficult to untangle the strands." (Maramureş, ed. by SUCHOFF, 28.)

${ }^{35}$ See melodies nos. 141b, 143b, 144, 145, 154c, 155, 157, 161a and 162 of the Maramureş volume and Bartók's notes referring to them.

${ }^{36}$ Maramureş, ed. by SUCHOFF, 28-29.

${ }^{37}$ Cf. melody no. 151a in the Maramureş volume.

${ }^{38}$ Cf. melody no. 171 in the Maramureş volume. About Bartók's method of transforming the folk melody into a piece of art in the case of the "Bear Dance" see László VIKÁRIUS, "Erinnern an die 'Stimmung' der Sache: Das Konkrete und das Schwebende im Komponieren Bartóks," in Resonanzen: Vom Erinnern in der Musik, ed. by Andreas DORSCHEL, Studien zur Wertungsforschung 47 (Vienna: Universal Edition, 2007), 165-168.

${ }^{39}$ The cylinders sent to Berlin contained melodies nos. 20a, 21b, 23a-c, 23i, 124, 143a-b, 154b-c, 164b, 164d, $174 \mathrm{~b}, 193$ and 195 of the Maramureș monograph, see Vera LAMPERT, "Bartók and the Berlin School of Ethnomusicology," Studia Musicologica 49 (September 2008), 386-388.
} 
probably the most interesting for Bartók. The first of the two pairs of melody on the first cylinder, a very fast Invârtită [Whirling Dance] (no. 154b) is a brilliant example of motivic variation: the violinist repeats and alternates two motifs in such a way that they almost never recur exactly the same way, thereby resembling the variation technique of the violinists of Ugocsa. The second melody (no. 154c) could be characterized in contrast as a "gypsy-like" variant. The other melody pair (no. 143a-b) shows even closer relation with the Ugocsa material; they make use of a motif that lies very close to motifs appearing in several of the Ugocsa melodies. Comparing the variant "a" of the melody with the melody of Tarna Mare quoted before, despite their obvious differences we can observe certain common features, such as the bagpipe imitating repetitive double stops, the descending melody line on the $\mathrm{A}^{2}-\mathrm{D}^{2}$ Lydian pentachord ${ }^{40}$ or the tendency of continuous repetition of a single two-measure motif with or without variation (see Examples 1a and 2a). Another peculiarity occurs in relation with these two dance melodies. Along with the Maramureş melody called De băut [Drinking dance] Bartók included in the publication its vocal variant, a simplified form of the instrumental melody, sung together with the variant "b" (see Example 2b). As Bartók observed, the melodies called De băut or Bătută din pălmi [Clapping Dance], played usually during feasts, are accompanied by the rhythmic clapping of the listeners who, at the same time, either recite dance words or sing a quasi-skeleton form of the melody. ${ }^{41}$ In our case this is a simple four-line stanza of eight (or seven) syllables per line with a rhythm of equal eighth notes, which is the most common structure of Romanian vocal dance melodies. ${ }^{42}$ As Bartók pointed out, in Ugocsa only the melodic type of vocal accompaniment is known. ${ }^{43}$ Although here he did not record any example of dance music with simultaneous playing and singing, he identified one of the vocal dance melodies as being identical with the violin melody quoted above (RFM/II, no. 520). ${ }^{44}$ Whereas their relationship is perhaps not so obvious at first sight, ${ }^{45}$ the structure of the vocal melody could actually reveal certain characteristics of the violin melody itself (see Example 1a, Example 1b). The vocal melody begins with a sharp exclamation ("Hei țuraaa") in the highest register ${ }^{46}$ the corresponding introductory part of the violin melody is missing from the transcription, but it can be heard on the phonograph recording: i.e., the violin begins with a series of bagpipe imitating repetitive double stops. The melody itself is made up of the repetition of a single eight-

\footnotetext{
${ }^{40}$ The notes under $\mathrm{D}^{2}$ in the Oncești melody are only ornamental notes, as other variants of the same motif attest, cf. also melody no. $143 \mathrm{~b}$.

${ }^{41}$ Maramureş, ed. by SUCHOFF, 23. According to the phonograph recording the two variants of our melody present both types of vocal accompaniment, cf. cylinder MH 2192a and b (Museum of Ethnography, Budapest).

${ }^{42}$ See Béla BARTÓK, Rumanian Folk Music, ed. by Benjamin SUCHOFF, vol. II: Vocal Melodies (The Hague: Martinus Nijhoff, 1967), 22-23.

${ }^{43}$ Maramureş, ed. by SUCHOFF, 28.

${ }^{44}$ Cf. Bartók's collecting field book “T.III,” fol. 32v. This connection is not mentioned in the published version of the melodies in Rumanian Folk Music. As later researches attest, the dance melodies of Oaş are performed usually on violin associated with singing, in more recent times also with guitar accompaniment that renders the syncopated rhythmic pattern common to all Danț melodies. (See BOUËT, et al., À tue-tête, 82-89.).

${ }^{45}$ In this respect the phonograph recording is more convincing, cf. cylinders nos. MH 1974a and 1976c (Museum of Ethnography, Budapest).

${ }^{46} \mathrm{Cf}$. Bartók's letter to Brediceanu, quoted at the beginning of this article. Due to its peculiar performance, that, during the past decades, have become even harsher, this melodic shouting is called țipuritură.
} 


\section{$143 \mathrm{a}$.}

(de băut)

F. : 2192 b)
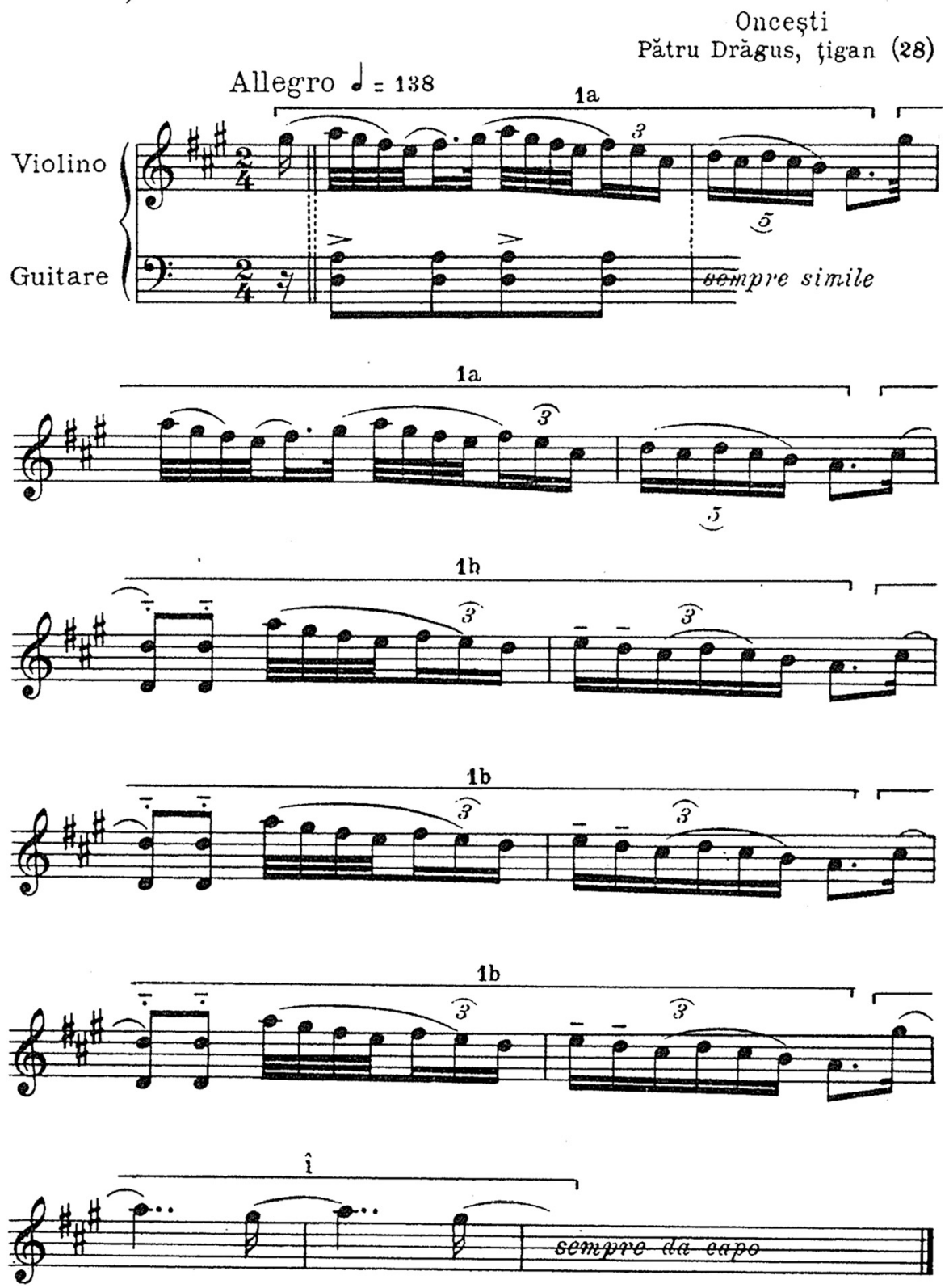

Example 2a. Dance melody with motif structure from Maramureş, Maramureş, no. 143a 
Tot aceasta cu text, în acest mod au cântat-o după vioară: Die Weise mit Text zur Geige gesungen (beim Tanz):
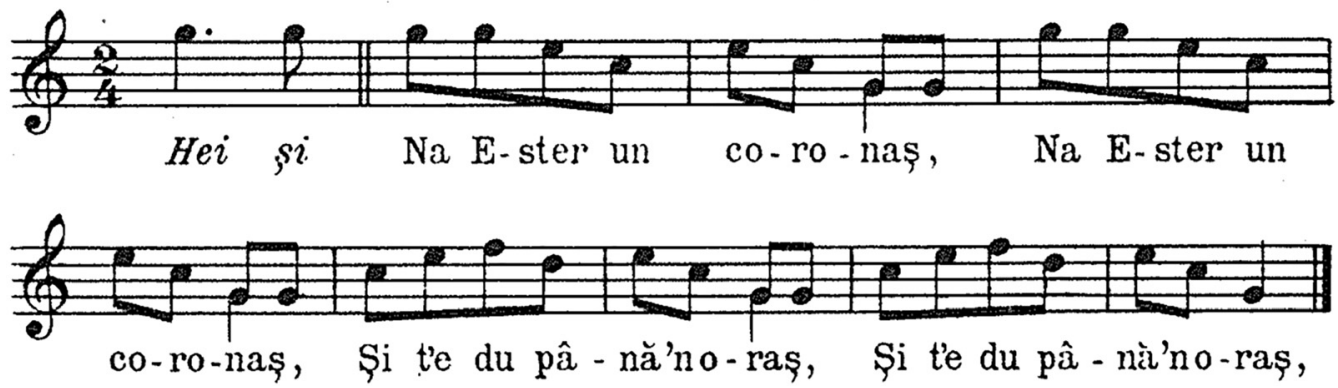

Example 2b. Vocal variant of the previous melody, Maramureş, no. 143a

or seven-syllable line. After each introductory exclamation a new statement of the melody starts. It begins with a descending line then, at every recurrence, it varies its shape in the course of which the ending of the line, which cadences on the lowest note of the scale, is the most invariable part. The violin melody shows the same tendency of motivic variation. Moreover, the opening descending line can also be discovered in the violin melody; it shows a clearer form for the second time (cf. at the middle of the fourths staff).

The simpler structure of the vocal melodies helps us better understand the construction of both violin melodies. The basic unit in both cases is a two-measure motif of equal eighth-note pulsation with similar melodic contour. The Ugocsa melody consists of the free repetition and constant variation of this two-measure motif, although its outlines are blurred to an even greater extent by the eccentric performance. The melody from Maramureș is more balanced, we could say "classic," with less marked tendency to improvisation. Instead, the organization of the motivic variation tends to be periodic. In the material of the Maramureş monograph we can find many De băut pieces of stanza form, some with vocal variants, sung either together with the instrument or independently. One of them, no. 177a, was arranged later by Bartók in the FortyFour Duos, for two violins (BB 104, no. 32 "Dance from Máramaros"). ${ }^{47}$ The relation of these vocal dance melodies with the proper songs (or non-ceremonial songs) of Maramureș, called here horas - to which connection Bartók called attention - could open up further perspectives into the investigation of the dance melodies. This would, however, lead us too far from our present concerns. The comparison of these two violin melodies was intended to show possible similarities between the dance music of these two neighboring counties, which despite their marked differences became closely interconnected in Bartók's musicological and creative thinking. In the continuation we shall take a short look at two cases where the violin music of these two areas comes into relief in Bartók's compositions.

\footnotetext{
${ }^{47}$ Although its main source was the vocal melody (see LAMPERT, Folk Music in Bartók's Compositions, 196.), the arrangement also recalls its violin variant, mainly through the open fifth accompaniment (this is missing from the transcription but is present on the recording of the folk melody, cf. phonograph cylinder MH 2159b). Its syncopated rhythm, however, is more characteristic of the Joc fecioresc [Young men's dance], the genre to which the vocal melody belongs.
} 
The beginning of the 1920s marks a clear change in Bartók's attitude toward the compositional use of folk music. In the Improvisations on Hungarian Peasant Songs (BB 83) for piano the Hungarian folk melodies - used as "mottos" for these eight pieces - appear incorporated into the composer's harmonically most daring, strikingly "radical" language. Although a set of folk song arrangements, Bartók considered it an original work in its own right - signaling this also by publishing it with an opus number. The following two Sonatas for Violin and Piano (BB 84, 85), on the other hand, are representative large-scale works of progressive style showing significant folk music influence but without making use of any direct folk music quotations. At the same time, the third movement of the First Violin Sonata is actually the very first example of the socalled quasi-folkloristic dance finale, a movement type frequently used by Bartók in the next decades. ${ }^{48}$ Moreover, as László Somfai pointed out, by using folk music models of different ethnic groups, it could be seen as an anticipation of the idea of the "brotherhood of peoples" of the Dance Suite (BB 86, 1923). ${ }^{49}$ Bartók's increased interest in using or reflecting on folk music material was very likely generated by the intense study of his prior folk music collections. Although the political changes in the wake of the First World War brought his long period of collecting trips to an end, from 1920 Bartók turned to the profound analysis and preparation for publication of his Hungarian, Slovak, and Romanian collections. ${ }^{50}$ The creation of the Violin Sonatas, however, seems to have been greatly influenced by Bartók's work with the Romanian folk music collection of Maramureş County, which after a long and stormy publication history finally landed at a publisher in 1921. ${ }^{51}$ Many studies analyzing the Violin Sonatas call attention to the supposed Romanian origin of several of their stylistic components. Here I will take a look only at the aforementioned finale of the First Sonata, and I will try to give a short account of its folkloristic background.

The First Violin Sonata, written for and inspired by the brilliant, young violinist Jelly Arányi, was a cornerstone of Bartók's repertoire on his first important concert tour in 1922 to London and Paris, with which, after a long period of silence, he could present himself and establish his position among the leading figures of contemporary composition. In this regard it was particularly important for Bartók to use a highly individual language. No wonder that he found the proper model for his planned finale in the virtuoso violin music of his Romanian collection. We

\footnotetext{
${ }^{48}$ See László SOMFAI, “'Per finire’: Some Aspects of the Finale in Bartók’s Cyclic Form,” Studia Musicologica 11 (1969), 391-408.

${ }^{49}$ László SOMFAI, "Progressive Music via Peasant Music? Revisiting the Sources of Bartók’s Style and Compositional Process," in The Past in the Present. Papers Read at the IMS Intercongressional Symposium and the 10th Meeting of the Cantus Planus. Budapest \& Visegrád, 2000, ed. by László DOBSZAY (Budapest: Liszt Ferenc Academy of Music, 2003), 499-513.

${ }^{50}$ Of the three folk music books only the monograph on Hungarian folk music was actually published in those years, see Béla BARTÓK, A magyar népdal [The Hungarian folk song] (Budapest: Rózsavölgyi, 1924); first English edition: Hungarian Folk Music, transl. by Michel-Dimitri CALVOCORESSI (London: Oxford University Press, 1931). Several musicological studies written by Bartók on these subjects could, however, be considered as preparatory material for his planned collected editions, see "Hungarian Peasant Music," Musical Quarterly 19, no. 3 (July 1933), 267-287 (written actually in 1920), reprinted in Essays, 80-102; "A tót népi dallamok" [The Slovak folk melodies] (1922, unpublished), first published in BBÍ/3, 166-209.

${ }^{51}$ See Bartók's letter to Ion Bîrlea on 4 March 1922 in Bartók Béla levelei [Béla Bartók letters], ed. by János DEMÉNY (Budapest: Editio Musica, 1976), 277. On the publication history see LÁSZLÓ, "Nochmals über die Folkloresammlung von Maramuresch."
} 


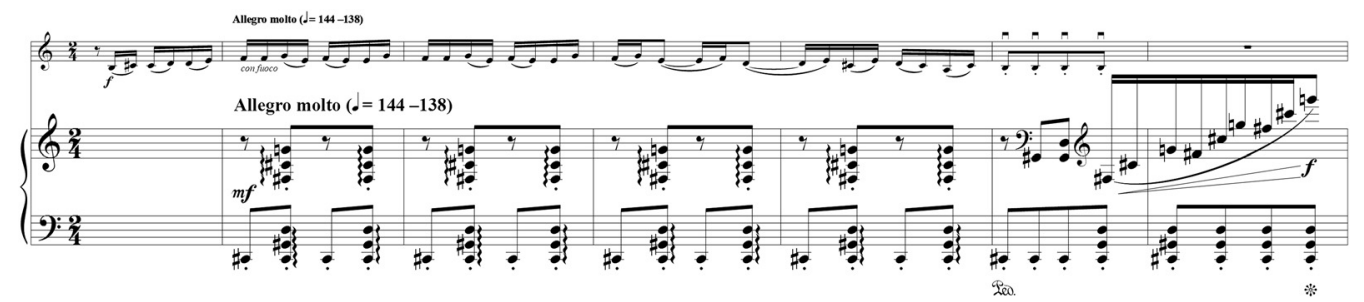

Example 3. First Violin Sonata, mov. III, beginning

should keep in mind that during his relatively short but extremely intensive period of folk music collecting Bartók came across a considerable amount of violin music only by Romanians, and this material, published later in the instrumental volume of his Rumanian Folk Music, was valued highly by him both as a folklorist and as a composer. The opening-theme of the finale, which with its rondo-like recurrences dominates the general character of the movement, is considered to have been modelled on Romanian violin music of the Maramureş region. In an essay of style analysis László Somfai presents the various observations of several Bartók researchers related to this topic; ${ }^{52}$ for a closer examination of the rondo theme I will take into account his survey.

Although the theme itself is completely Bartók's own invention and, moreover, it is not modelled on any specific folk melody, there are some elements in it that can be traced back to the peasant music collected in Maramureș (see Example 3). The vigorous rhythmic performance with legato pairs of sixteenth notes is characteristic of the peasant violin music in general. János Kárpáti makes reference to melodies nos. 187b and 190 of Bartók's Maramureș monograph (Example 4a-bExample 4a, Example $4 \mathrm{~b}){ }^{53}$ where passages with similar technique play an important role. It is interesting to observe, though, that in the peasant music models such passages are regularly descending rather than ascending. No. 190 is also interesting because of its tonal structure: the melody oscillates between two tonal centers, D major and B minor. Towards the end the two centers appear condensed within a two-measure motif. In the Sonata this ambiguity is reflected in a more complex way. The opening melody of the violin shows an archshaped contour with a clear cadence on the fifth degree, perceptible also as a temporary tonal shift to the diminished fifth of the scale; this is repeated four times, always varied and gradually expanding upwards, emphasizing the same tritone framework but with chromatically gradually denser texture. This ambiguity of the tonal center could be related to the tendency towards a plagal cadence, i.e., a shift to the lower fifth that Bartók observed frequently in the vocal melodies of Maramureş, making him uncertain about the tonality of these melodies and, consequently, about their classification. ${ }^{54}$

The piano accompanies the violin with repeated chords of perfect and diminished fifths piled upon one another and based on C sharp, the tonal centre of the whole composition. This pedal-

\footnotetext{
${ }^{52}$ SOMFAI, "Progressive Music via Peasant Music?," 503-505.

${ }^{53}$ János KÁRPÁTI, Bartók's Chamber Music (Stuyvesant, NY: Pendragon, 1994), 304.

${ }^{54}$ See Maramureş, ed. by SUCHOFF, 17-18.
} 

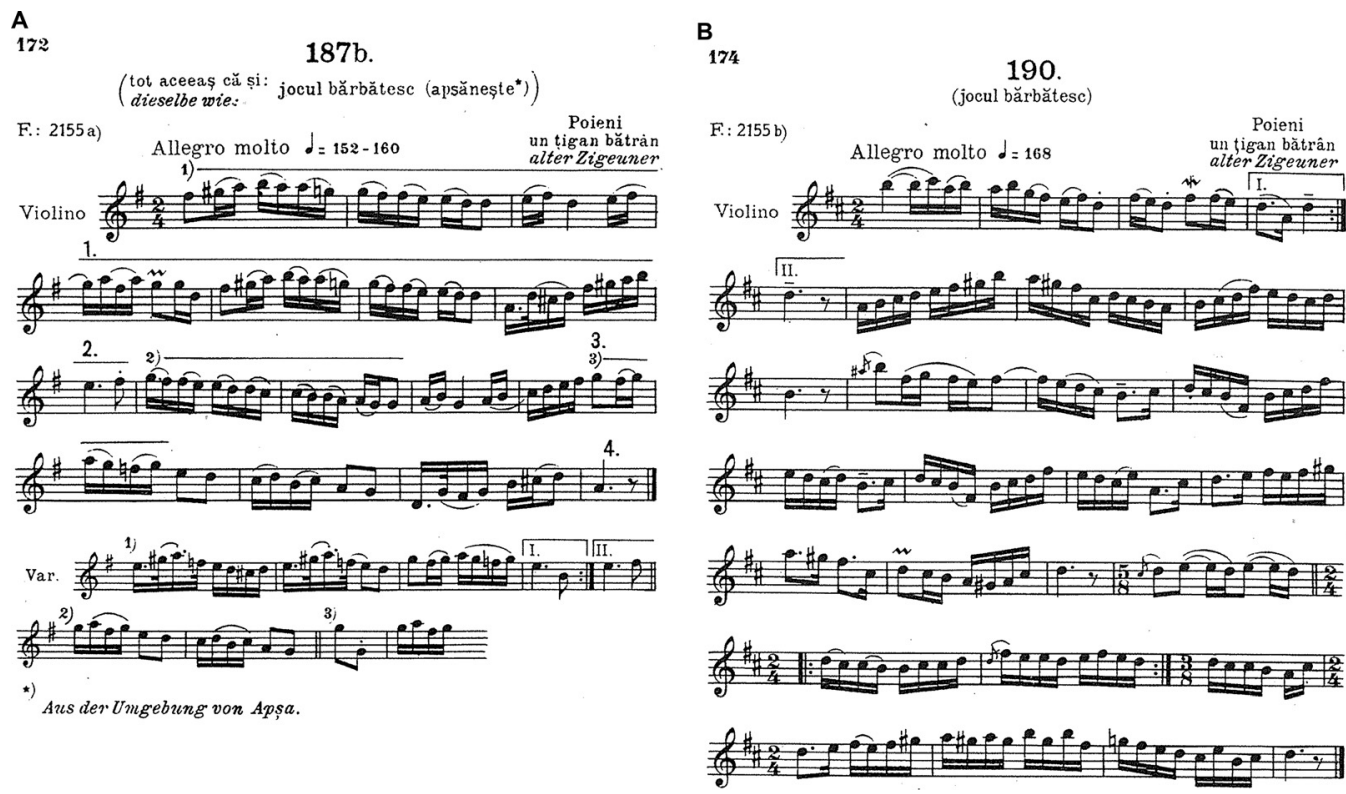

Example 4a-b. Possible peasant music models of the opening theme of the Finale of the Violin Sonata: Maramureş, no. $187 \mathrm{~b}, 190,146,165$

like accompaniment unmistakably resembles the guitar accompaniment of the violin melodies of Maramureş. ${ }^{55}$ As it has been mentioned before, this obstinate eighth-note accompaniment on the D-A open fifth of the two-stringed guitar is in essence a rhythmic accompaniment, thus it is not necessary to be in tune with the violin's melody - and this is the case with several pieces of the Maramureş collection, as well as with its stylized recreation in the rondo theme of the Sonata.

Melody no. 146, quoted by John W. Downey as a possible model for the rondo theme, ${ }^{56}$ is a remarkable example of motivic variation by a peasant violinist, a technique that could have found its way into Bartók's composition in various forms (see Example 4c). The "old gypsy" of Poieni played the same melody first as a fast Învârtit $\breve{a}$ [Whirling dance], then as a Bătută din pălmi [Clapping Dance] of more moderate tempo, both with several variations of a single motif - here we quote only the beginning of variant "a" of the melody. Some of the figurations related to certain whirling motifs of the violin melody of the Sonata contain interesting shifted accents. As László Somfai observes, the motivic elaboration of the rondo theme makes use of several different characteristics of Romanian peasant music, including shifted rhythm. ${ }^{57}$

\footnotetext{
${ }^{55}$ A connection also pointed out by David COOPER, see his Béla Bartók (New Haven: Yale University Press, 2015), 185186. The two folk melodies quoted before have also been accompanied by the guitar, even though this does not appear in the transcription, cf. the phonograph recording of the melodies (MH 2155a-b).

${ }^{56}$ DOWNEY, La musique populaire dans l'œuvre de Béla Bartók, 350-351.

${ }^{57}$ SOMFAI, "Progressive Music via Peasant Music?," 504.
} 
c
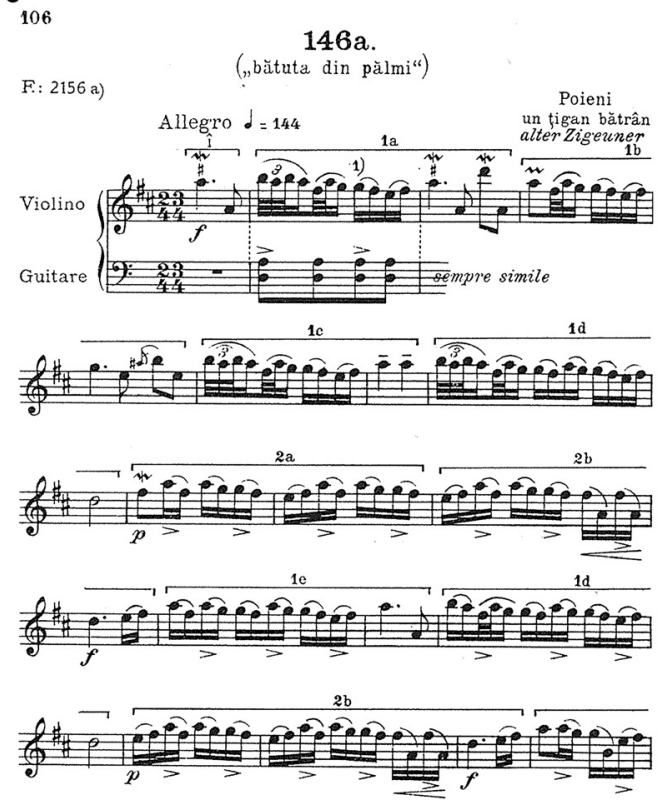

D

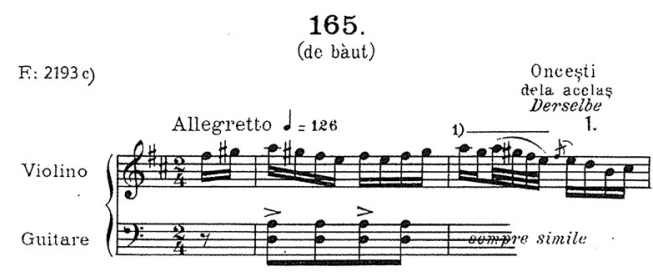

2.
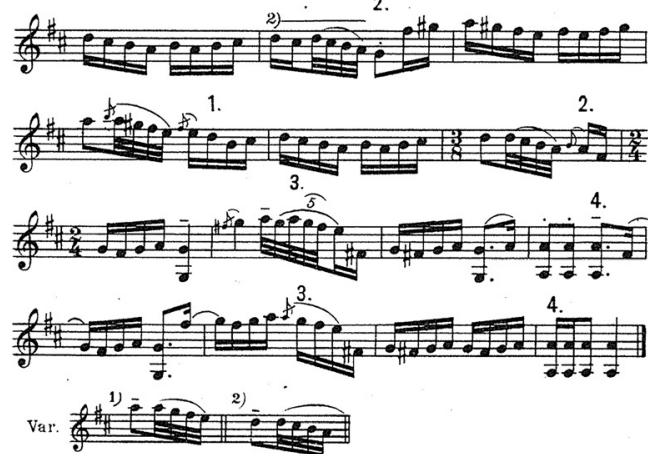

\section{Example 4c-d.}

Another element emphasized by Somfai requires more attention. Scales with so-called "mistuned" octaves appear towards the end of the transition section resembling some peculiar scales discussed in detail by Bartók in his Maramureş monograph (see Example 5). ${ }^{58}$ In the introductory study of his book Bartók explained the scales that contain $\mathrm{F}^{1}$ and $\mathrm{F}^{2}$-sharp in the same melody as being built of two conjunct pentachords. ${ }^{59}$ The scale consisting of two Lydian pentachords is the tonal framework of melody no. 165, one of the examples referred to by David Cooper with regard to the rondo theme of the Sonata (see Example 4d). ${ }^{60}$ Although in the composition this particular scale appears, again, transformed, the "impact" of hearing it on the spot was without doubt of far-reaching consequences for Bartók. Despite the fact that this is a unique example in his Maramureș collection, Bartók specifically analyzed it in the introduction of his monograph. Furthermore, in a later lecture, "New Results of Folk Song Research in Hungary," he illustrated the violin music with a dance melody in Bulgarian rhythm from the Banat region and four melodies from Maramureş (out of which three were

\footnotetext{
${ }^{58}$ Although similar passages appear in melody no. 173h mentioned by Benjamin SUCHOFF, cf. his Bartók, Concerto for Orchestra: Understanding Bartók's World (New York: Schirmer Books, 1995), 76-77, this apparent bimodality is only resulted from the frequent use of leading notes and does not belong to the very essence of the melody.

${ }^{59}$ Maramureş, ed. by SUCHOFF, 20, 27. Here it should be noted that in both cases the melodies in question have a descending fifth-shifting structure, i.e., the first two lines of the melody are played in the third and fourth lines transposed a fifth lower. The upper scale appears in a vocal melody arranged later by Bartók as no. 7 ("Walachian Song”) in the Forty-Four Duos, for two violins (see LAMPERT, Folk Music in Bartók's Compositions, 184.)
}

${ }^{60}$ COOPER, Béla Bartók, 185-186. 

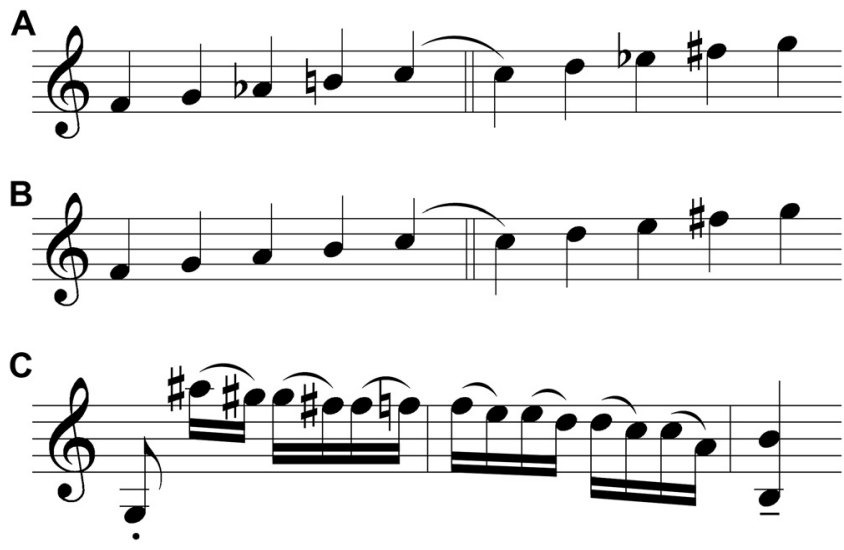

Example 5a-c. Scales with "mistuned" octaves in the Maramureş collection and their reformulation in the Violin Sonata

performed by Drăguş). Among these the melody with a "mistuned" octave mentioned above also figured. ${ }^{61}$ The scale is interesting in another respect as well. A Lydian pentachord is the base of the so-called acoustic scale, which, as mentioned before, provides the tonal structure of the majority of the dance melodies, especially of those with motif structure collected by Bartók in Maramureş. Regarding the rondo theme of the Sonata, many previous studies have observed that the scale of the violin's melody can be considered as a variant of the acoustic scale.

The rondo theme of the First Violin Sonata is only a short excerpt to illustrate the "deep comprehension" of the folk music of Maramureş and its infiltration into Bartók's composition. In the late 1920s Bartók turned once again to the music of this region, this time building a significant portion of a large-scale work on the virtuoso and eccentric motivic dance melodies of Ugocsa County. ${ }^{62}$ The two Violin Rhapsodies (BB 94a, 96a) dedicated to Joseph Szigeti and Zoltán Székely, Bartók's two most famous violinist partners, were inspired by Bartók's concert experiences. The violin and piano arrangements of the Romanian Folk Dances (BB 68, 1925) and of a selection of pieces from the For Children series (BB 53, 1926),

\footnotetext{
${ }^{61}$ See Béla BARTÓK, "Neue Ergebnisse der Volksliedforschung in Ungarn,” Anbruch: Monatsschrift für moderne Musik 14, nos. 2-3 (February-March 1932), 37-42; in English: Béla BARTÓK, Studies in Ethnomusicology, ed. by Benjamin SUCHOFF (Lincoln: Lincoln University Press, 1997), 37-42; lecture version with illustration material in Bartók Béla írásai [Béla Bartók writings] 4, ed. by Vera LAMPERT, Dorrit RÉVÉSZ, and Viola BIRÓ (Budapest: Editio Musica, 2016), 421-441.

${ }^{62}$ On the problem and method of arranging folk melodies with motif structure see Vera LAMPERT, "Motívumos néptáncok Grieg és Bartók műveiben" [Motivic dances in the works of Grieg and Bartók], Magyar Zene 48, no. 2 (2010), 187-202. On the peculiar performance of motivic dance melodies and their influence on Bartók's compositions see Márta PAPP, “Bartók hegedürapszódiái és a román népi hegedűs játékmód hatása Bartók müveire” [Bartók’s Violin Rhapsodies and the influence of the Romanian peasant violin playing on Bartók's works], Magyar Zene 14, no. 3 (1973), 299-308.
} 
respectively, transcribed by the same two violinists, can be considered as immediate precursors to them. The Rhapsodies were probably written partly in return for Szigeti and Székely's efforts to popularize Bartók's works through their earlier arrangements. The genre of rhapsody seems to have been, at that time, the most suitable choice for Bartók, as he aimed to compose brilliant concert pieces. His attitude toward the Lisztian genre had changed, however, considerably during the previous two decades. The Rhapsody for piano (and for piano and orchestra), op. 1, (BB 36a, b) his youthful work assigned as the cornerstone of his creative maturity, reforms the genre by presenting it as a serious largescale work of original material with pronounced Hungarian character but ambitious motivic elaboration. Following his folk music collecting trips Bartók reconsidered the rhapsody form by including in the fourth volume of For Children a slow-fast pair of pieces under the title "Rhapsody" (nos. 40-41 in the first edition), thus regarding it as a character piece based on folk material. The Violin Rhapsodies of 1928-1929 represent Bartók's probably most elaborate arrangements of folk music: considering the manner and measure of working with the source melodies, the compositions stand at the border-line of what could be called folk music arrangement in Bartók's terms. ${ }^{63}$ Using violin music of Hungarian, Romanian, and Ruthenian origin Bartók engaged himself in evoking as faithfully as possible the peculiarities of peasant violin playing while at the same time adjusting them to the demands of stage performance. $^{64}$

The second part (Friss) of the Second Violin Rhapsody is perhaps the most unusual for the ordinary listener, while at the same time it is technically the most demanding for a classically trained musician. Its unusual character is due partly to the peculiar performance of the bagpipeimitating melodies with motif structure and partly to the specific compositional technique required by these melodies of free structure. The seven folk dance melodies used in it follow each other in a free chain-like form, where the task of binding them together in an organically closed structure imposed difficulties on the composer. ${ }^{65}$ The arrangement shows, however, a welldesigned, coherent structure. As Vera Lampert has pointed out, the selection of specific melodies showing motivic correlations was an essential concern in creating the unity of the work. ${ }^{66}$ Furthermore, in a previous study I have shown that actually the whole design of the work reveals a clear formal dramaturgy that also reflects Bartók's ethnomusicological findings: the succession of dances, both tonally and motivically related to one another, outline a kind of evolutionary progression from free motif structure to strophic form. ${ }^{67}$

\footnotetext{
${ }^{63}$ Cf. Bartók's famous three-fold categorization of using folk music in his "The Influence of Peasant Music on Modern Music," in Essays, 341-344.

${ }^{64}$ For the source melodies see LAMPERT, Folk Music in Bartók's Compositions, 160-169.

${ }^{65}$ For these compositional problems see also articles dealing with the alternative endings of the Rhapsody: László SOMFAI, Béla Bartók: Composition, Concepts, and Autograph Sources (Berkeley, California: University of California Press, 1996), 198-202; Fiona WALSH, "Variant Endings for Bartók’s Two Violin Rhapsodies (1928-1929)," Music \& Letters 86, no. 2 (May 2005), 234-256; Vera LAMPERT, “The Evolution of Alternative Endings: Once Again about the Closing Section of Bartók's Second Rhapsody for Violin and Piano” (manuscript).

${ }^{66}$ LAMPERT, “Motívumos néptáncok Grieg és Bartók műveiben,” 197.

${ }^{67} \mathrm{Cf}$. my article “Adalékok Bartók 2. hegedűrapszódiájának népzenei forrásaihoz" [Reconsidering the folk music sources of Bartók’s Second Violin Rhapsody], Magyar Zene 50, no. 2 (May 2012), 188-209.
} 
From the direct use of individual melodies in compositions like the Sonatina, the Forty-Four Duos, or the Second Violin Rhapsody, to more abstract appearances of some of their peculiarities like those in bagpipe-imitating music, the peasant violin music of Maramureş had a long-term influence on the composer.

Open Access. This is an open-access article distributed under the terms of the Creative Commons Attribution 4.0 International License (https://creativecommons.org/licenses/by/4.0/), which permits unrestricted use, distribution, and reproduction in any medium, provided the original author and source are credited, a link to the CC License is provided, and changes - if any - are indicated. (SID_1) 